\title{
A Rent-Seeking Model of Voluntary Overcompliance: Addendum
}

\author{
Marco A. Haan ${ }^{1}$
}

Accepted: 12 February 2016 / Published online: 11 March 2016

(C) The Author(s) 2016. This article is published with open access at Springerlink.com

\begin{abstract}
In a previous paper (Haan in Environ Resour Econ, 2016) I missed some relevant literature essentially related to that paper. In this addendum I discuss how two earlier contributions (Graichen et al. in Public Choice 108:273-293, 2001; Liston-Heyes in J Environ Econ Manag 41:1-12, 2001) are related to Haan (Environ Resour Econ, 2016), and how Haan (Environ Resour Econ, 2016) differs from those contributions.
\end{abstract}

Keywords Voluntary overcompliance $\cdot$ Regulation $\cdot$ Rent-seeking

JEL Classification Q50 - D72 · L51

\section{Introduction}

After acceptance of my paper A Rent-Seeking Model of Voluntary Overcompliance (Haan 2016), it has been brought to my attention ${ }^{1}$ that mine is not the first paper in which a polluting firm behaves more environmentally friendly in an attempt to essentially lower the stakes of an environmental group in the rent seeking game that ensues. Needless to say, this literature, of which I was unaware when I submitted my paper to this journal, should have been referenced in my paper. I am grateful to the Editor, Michael Finus, for giving me the opportunity to write an Addendum and to give credit where it is due. Below I give a short overview of that literature, and also discuss how it relates to my paper.

1 Thanks to Bouwe Dijkstra for pointing this out.

This paper is an addendum to the article published with DOI:10.1007/s10640-015-9973-2.

Marco A. Haan

m.a.haan@rug.nl

1 IEEF, Faculty of Economics and Business, University of Groningen, PO Box 800, $9700 \mathrm{AV}$, Groningen, The Netherlands 


\section{Related Literature}

In Liston-Heyes (2001) (L-H henceforth), a developer wants to undertake a project of fixed size that will earn it profit $\pi$ but also cause external damage $D(\pi)$, where $D$ is increasing and convex in $\pi$. An environmental group and the developer then play a rent-seeking game, where the prize for the environmental group is $D(\pi)$ (if it wins, it can avoid environmental damage of that size), whereas the prize for the developer is $\pi$ (if it wins, it can make profits $D)$. L-H shows that, because of the contest, the developer will choose a project size $\pi$ that is smaller (and hence environmental damage that is lower) than what she would choose without a contest. However, the environmental project size is still too large from a welfare perspective. In her paper, L-H especially focuses on the timing of lobbying expenses, which in her model can be determined by the social planner.

In Graichen et al. (2001) (GRD henceforth), a monopolist energy firm produces a quantity $q$ by causing a certain amount of pollution $e$, causing perceived damage $D(e)$ and allowing for profits $\pi(e),{ }^{2}$ which is increasing in $e$. The monopolist and an environmental group play a rent-seeking game on whether the contract with the monopolist should be renewed. Also here, the prize for the monopolist is $\pi(e)$, whereas the prize for the environmental group is $D(e)$. Also here, the monopolist can influence the lobbying game by their choice of $e$ (and hence $\pi$ ). As in $\mathrm{L}-\mathrm{H}$, when having to lobby, the environmental group chooses a pollution level that is lower than it would otherwise be.

Hence, both in L-H as well as in GRD, the firm essentially proposes a project that will be carried out if it wins the rent-seeking contest. By making that project more environmentally friendly, the firm influences that contest. In Haan (2016), the firm already makes an irrevocable investment in abatement before entering the contest. Although the mechanisms are very similar, that makes mine a model of voluntary overcompliance, where L-H and GRD are not. In those papers, firms pollute less than what they would do without a contest. In my paper, firms pollute less than what current regulation requires. In L-H and GRD, firms influence the contest by committing to be more environmentally friendly should they win. Hence, these papers apply to situations where those commitments are credible. In Haan (2016), firms influence the contest by already being more environmentally friendly before the contest starts, ${ }^{3}$ and credibility is not an issue.

Epstein and Nitzan (2004) propose a more general model. In their paper, two players play a two-stage contest. In the first stage, each player proposes a policy. In the second stage, a contest takes place where the winning player gets to implement her proposed policy. By strategically choosing the first-stage policy, players can influence the contest, and hence their chances of winning and lobbying costs. Note that both L-H and GRD can be interpreted as special cases of this model, where only one player can act in stage 1. Again, Haan (2016) is somewhat different as the firm already takes an action in stage 1 , rather than just making a proposal.

Open Access This article is distributed under the terms of the Creative Commons Attribution 4.0 International License (http://creativecommons.org/licenses/by/4.0/), which permits unrestricted use, distribution, and reproduction in any medium, provided you give appropriate credit to the original author(s) and the source, provide a link to the Creative Commons license, and indicate if changes were made.

\footnotetext{
2 Or, in their notation, $M(e)$; I change the notation to be consistent with L-H.

${ }^{3}$ Of course, there are more differences between the three papers, e.g. in terms of modeling decisions and focus.
} 


\section{References}

Epstein GS, Nitzan S (2004) Strategic restraint in contests. Eur Econ Rev 48:201-210

Graichen PR, Requate T, Dijkstra BR (2001) How to win the political contest: a monopolist vs environmentalists. Public Choice 108:273-293

Haan MA (2016) A rent-seeking model of voluntary overcompliance. Environ Resour Econ. doi:10.1007/ s10640-015-9973-2

Liston-Heyes C (2001) Setting the stakes in environmental contests. J Environ Econ Manag 41:1-12 